\title{
Roles of Organizational Support in Quality of Work Life in Insurance Industry
}

\author{
R. Rozaini, A. W. Norailis, and B. Aida
}

\begin{abstract}
In current business scenarios, the workforce in Malaysia has often called to acquire core competencies and maintain their competitiveness in a global market. Further, with the implementation of various policies pertinent to employment including the retirement age and minimum wages, the workplace is no more a pleasant place. Workers need to be more innovative, creative and talented to sustain employment. For such reasons, this paper attempts to examine the relationship between quality of work life and organizational support in insurance industry. The results showed that satisfaction with the job $(M=3.68)$; successful people, directed or influenced by its own commitment to achieve organizational goals $(M=3.55)$; know and understand the policies and processes to do their job better $(M=3.54)$. These results are important because it show the relationships between job satisfaction and organizational support are intertwined and closely related to organization performance. This paper proposed practical solutions that help management or decision-makers to highlight the most influential factors in the development of their organization.
\end{abstract}

Index Terms-Organizational support, quality of work life, job satisfaction, insurance industry.

\section{INTRODUCTION}

Nowadays business environment is changing very fast; the organizational threats came largely from a few domestic competitors due to the information preparation, product life cycles and competitive advantages. The changes in technology like e-business and e-commerce have created a quantum leap information availability and control of doing business. With the impending move toward globalization and liberalization of economic, organizations should prepare and cope with the rapid changes in the business dynamics. Each organization must submit and varying demands of changes in the workplace environment [1]. Changes within an organization take place in response to business and economic events and to processes of managerial perception, choice, and actions where managers see events taking place that indicated the need for change [2]. The corporation had 'delivered', throwing off entire levels of management and it was 'disaggregated', ridding itself of its extraneous operations; it embraced 'flexibility', making it easier to replace career workers with (zero-benefit) temps and 'disinter mediated' with new technology system.

Manuscript received February 14, 2014; revised April 24, 2014.

The authors are with the Faculty of Economics and Muamalat, Universiti Sains Islam Malaysia (e-mail: rosrozaini@yahoo.com, norailis@usim.edu.my, aidanazri2002@yahoo.com).

\section{LITERATURE REVIEW}

\section{A. Organizational Support}

Organizations are continuously looking for new ways of doing business in order to meet the challenges of today's dynamic business environment. Given the amount of time and energy people expend at the workplace, it is important for workers to satisfy their entire life. Workers perceived different aspects of the treatment would actually influence [3].

Organizational support is defined as the extent to which workers perceive that the organization values their contributions and cares about their wellbeing [4]. This is a key factor in influencing worker commitment to the organization, job satisfaction, and general quality of work life. In today's competitive business environment, workers of organizations can be viewed as representing a unique organizational resource, which can be used for gaining competitive advantage under a work environment that is conducive for human work. Organization support is one of the most important organizational concepts that keep workers in the organization, since organizational support is known as a key factor in increasing job satisfaction and the organizational commitment of workers [5].

Organizational support and consequently the ability to influence is how the workers interpret the motives underlying the treatment by the organization. Organizational leaders would have to seriously look into addressing organizational-supported policies and programs in an effort to preserve an acceptable level of perceived organizational support [6].

Previous research also found that organizational support was a more significant predictor of organizational commitment than was supervisor support and mentoring. This result is being capable of distinguishing between, perceived organizational support and perceived team support of the workers. A worker also able to distinguish perceived team support plays merely a supporting role, whereas perceived organizational support is from the organization. A common example of team support is mentoring and coaching programs. Subsequently, examples of organizational supported programs could include socialization interventions fair operating procedures, rewards and job conditions [7].

An organizational environment conducive for human work requires the creation of work conditions can enhance the quality of an worker's work life in the organization, increased performance and productivity In other words, the organizational environment must have the capacity to satisfy meaningfully an worker's organizational and personal needs, 
and also the ability to shape' organizational values.

The potential workers on commitment and motivation will include selective hiring, appraisal, compensation, training and development activities. Organizational support is defined as the workers' global beliefs with regards to the extent, to which the organization values their contributions and cares about their well-being [8]. Since workers make attributions about the organizations, they can perceive their treatment as whether the organization favors or disfavors them. Attribution processes of workers are used to infer organizational support. These attribution processes are based on experience concerning the caring or non-caring intentions of policies, norms, or actions of an organization that affect workers.

Many companies are competing with organizations in neighboring countries that offer salaries as much as two to three times higher and with favorable foreign exchange rates. It becomes even more important for companies in Malaysia to look at creative measures to retain talent from offering competitive remuneration and formal learning programs, through to encouraging a family-friendly work environment that offers additional benefits like child care facilities and flexible working hours.

\section{B. Quality of Work Life}

The concept "quality of work life" was first discussed in 1972 during an international labor relations conference. It received more attention after United Auto Workers and General Motors initiated a quality work life program for work reforms. Robin [9] defined quality work life as a process by which an organization responds to employee needs by developing mechanisms to allow them to share fully in making the decisions that design their lives at work". In other words, it refers to the relationship between a worker and his environment, that can be broken down into different dimensions like the social, technical and economic, in which the work is normally viewed and designed.

Likewise, Malaysian government in unveiling Vision 2020 in the early 1990s has adopted cultures and life style of other countries such as Japan to balance between economy and social life [10]. In realizing the aspiration of the country and happier work life, Malaysia has carried out researches in 2012 regarding the perception of managers about their workplace and how they attribute the changes in the evolving patterns of work and organizational structures that affect their working and non-working lives [11]. The researches mainly explore four themes such as perceptions of organization and workplace; management and leadership styles, working hours and the effects of working hours have on managers and strategic performance of organizations.

Quality work life is a philosophy and a set of principles, which holds people into the most important resource in the organization as they are trustworthy, responsible and capable of making valuable contribution and treated with dignity and respect [12]. According to Table I, Malaysia was ranked at number 36 across 111 countries; showed an improvement as compared to Quality of Life 2008 (Malaysia was at 81st place with the final score of 58 points among the 202 countries that were ranked). One of the components highlighted in the Malaysian Quality Life Index is working life conditions, which looked at the working environment such as the unemployment rate and trade dispute. Besides, satisfaction of workers needs thorough resources, activities and outcomes stemming from participation in the workplace also measured through the index.

\begin{tabular}{|lcc|lcc|}
\hline \multicolumn{1}{|c|}{ TABLE I: WORLDWIDE QUALITY INDEX } \\
\hline Ireland & Score & Rank & Country & Score & Rank \\
Switzerland & 8.333 & 1 & Costa Rica & 6.624 & 35 \\
Norway & 8.068 & 2 & Malaysia & 6.308 & 36 \\
Luxembourg & 8.051 & 3 & Hungary & 6.534 & 37 \\
Sweden & 7.937 & 5 & Brazil & 6.470 & 39 \\
Australia & 7.925 & 6 & Thailand & 6.436 & 40 \\
\hline
\end{tabular}

Sources: The economic intelligent unit (2005).

The overall improvement in the economic development of the nation was also reflected in the increase in the quality of life of the population at the state level. This is attributed to various strategies at the federal and state levels. In line with this, the Ninth Malaysia Plan (2006-2010) sets out to achieve a stronger and more value-added economy, while giving substantial focus to socio-economic issues and uplifting the quality of life for all. As a consequence to the satisfied and conducive working environment, quality work life enhances business performance. As evidenced by the data in Table II, it shows that $78 \%$ of respondents supported to the view that organizations commitment, $74.5 \%$ of respondents felt secure in their jobs. On the positive side, $62.8 \%$ found that they were encouraged and rewarded for creative behavior. However, at the same time, there was also a strong feeling $64.7 \%$, that their companies expected and rewarded them for compliance behavior to the chain of command. This was indicative of presence of a hierarchical structure.

TABLE II: REWARD, EQUITY AND VALUE

\begin{tabular}{|c|c|}
\hline Health and Well-being & $\%$ Agreed \\
\hline My well-being is taken seriously in this organization & 78 \\
\hline Many people in this organization feel stressed out & 56.9 \\
\hline $\begin{array}{l}\text { Many people have a sense of powerless in this } \\
\text { organization }\end{array}$ & 51 \\
\hline $\begin{array}{l}\text { Many people feel under pressure to work beyond their } \\
\text { contract and specified hours }\end{array}$ & 44 \\
\hline I have witnessed bullying in this organization & 24 \\
\hline \multicolumn{2}{|l|}{ Reward, equity and value } \\
\hline $\begin{array}{l}\text { This organization will provide me with a secure job for } \\
\text { the foreseeable future }\end{array}$ & 74.5 \\
\hline Creativity is rewarded in this organization & 62.8 \\
\hline $\begin{array}{l}\text { Employees are treated as this organizations most } \\
\text { important asset }\end{array}$ & 70 \\
\hline $\begin{array}{l}\text { Poor performance is quickly dealt with in this } \\
\text { organization }\end{array}$ & 66 \\
\hline Compliance is rewarded in this organization & 64.7 \\
\hline I often feel that I am being exploited in this organization & 32.7 \\
\hline Employee are last to hear about changes that affect them & 46 \\
\hline
\end{tabular}

Sources: Preliminary report, Malaysia quality work life (2012).

In terms of health and well-being, pressures to work well beyond contracted hours accounted for $44.0 \%$, surface in terms of a sense of alienation and powerlessness (51.0\%) and 
stress $(56.9 \%)$. For rewards, equity and value, $32.7 \%$ felt that they were exploited by their organizations. Among the programs under the work life balance are corporate concierge, maternity, paternity and adoption support and eldercare and child care services which are designed to help reduce stress and to ease their personal life. It was able to significantly reduce absenteeism, retain the best and loyal workers and increased in worker's productivity, which indirectly pushed the company forward.

\section{Job Satisfaction}

Job satisfaction represents a combination of positive or negative feelings that workers have towards their work, it is a complex variable and is influenced by situational factors of the job as well as the dispositional characteristics of the individual [13]. It is one of the most widely used variables in organizational behavior and it is important to an organization's success. Job satisfaction refers to how well the job provides the fulfillment of a need or want, or how well it serves as a source or means of enjoyment. According to Rose [14], a worker is intrinsically satisfied if they receive no apparent reward except the activity itself, while extrinsic satisfaction is defined as the opposite concept (that is, an worker is extrinsically satisfied if he receives monetary compensation or other material rewards to modify his behavior).

The survey of 405 employees in Malaysia from Employee Job Satisfaction in Malaysia 2012 [15] also found that two in five $(42 \%)$ would quit their jobs if there were no more room for personal development. This figure is even higher $(62 \%)$ for workers aged 18-24. Younger workers are generally more ambitious in their climb up the corporate ladder. They are more likely to change jobs, even if it means moving overseas, in order to gain more work experience, as well as higher pay. In this aspect, business leaders need to recognize the importance of offering opportunities for training and career development to help this group enhance their professional skills and stay loyal to their organization. From the same research, $78 \%$ of the respondents claimed that they were unhappy with their current job, most of the plan was stick with their current employer rather than jump ship.

Mcadam [16] studied the relationship between job satisfaction and organization support, the organizational commitment, and commitment to career development was a concept of "career flexibility" among the members of the profession. This is supported by Randstad Award from Global Finance (Banking and Insurance) for Q2 2012 [11] shows that three in five $(62 \%)$ employees in Malaysia consider a good salary more important than job satisfaction. This figure is among the highest from a global survey of 32 countries, with respondents across the region placing less emphasis on remuneration in China (55\%), Japan (52\%), Singapore $(51 \%)$, Australia (35\%) and New Zealand $(32 \%)$. The surveys also presented that more than one million Malaysians working abroad, attracting and retaining talent is a challenge in Malaysia.

\section{Methodology}

This paper employed survey method by using self-administered questionnaire. In order to suit the objectives of the research, these items were adapted from standard application produced by National Institute of Occupational Safety and Health (NIOSH). This questionnaire had been given to the respondents by end of 2013 to 155 workers in one insurance company in Malaysia. 94 completed questionnaires used in the analysis, which gave a usable rate of 60.7 percent. The result was 0.945 from the reliability analysis, showed a strong inter-item consistency reliability of the items measured.

\section{RESUlTS AND DiscUSSION}

For the purpose of the study, Table III summarized the sources of demographic profile of the respondents. The personal profile includes the nationality, age, gender, marital status, and years of experience in the present insurance.

TABLE III: DEMOGRAPHIC PROFILE OF THE RESPONDENTS

\begin{tabular}{|llc|}
\hline & Characteristics & Percentage \\
\hline Rank & Executive & 34.0 \\
& Non-executive & 66.0 \\
Marital & Single & 44.7 \\
status & & \\
& Married & 48.9 \\
& Divorced & 6.4 \\
Tenure & 0-3 years & 23.4 \\
& 4-9 years & 17.0 \\
& 10-19 years & 45.7 \\
& 20 years and above until 55 years old & 13.8 \\
\hline
\end{tabular}

TABLE IV: MEANS AND STANDARD DEVIATIONS FOR ORGANIZATIONAL

\begin{tabular}{|c|c|c|c|}
\hline No. & $\begin{array}{l}\text { SUPPORT } \\
\text { Item }\end{array}$ & Mean & SD \\
\hline 1. & $\begin{array}{l}\text { I am more concerned about developing my } \\
\text { own career than assisting in the development } \\
\text { of this organization. }\end{array}$ & 2.56 & 1.39 \\
\hline 2. & $\begin{array}{l}\text { I always feel comfortable about my talent } \\
\text { and satisfied with my job. }\end{array}$ & 3.34 & 1.19 \\
\hline 3. & $\begin{array}{l}\text { I am working in the organization that helps } \\
\text { me balance the demands of my work and that } \\
\text { of my family. }\end{array}$ & 2.94 & 1.19 \\
\hline 4. & $\begin{array}{l}\text { I believe my compensation reflects my } \\
\text { relative value in the organization. }\end{array}$ & 3.11 & 1.34 \\
\hline 5. & $\begin{array}{l}\text { I believe think senior management manages } \\
\text { changes well in my organization }\end{array}$ & 3.10 & 1.56 \\
\hline 6. & $\begin{array}{l}\text { I believe organization make it easier to } \\
\text { develop desirable skills. }\end{array}$ & 4.22 & 0.86 \\
\hline 7. & I have no problem working extra hours. & 3.80 & 1.18 \\
\hline 8. & I have strong sense with my organization & 2.95 & 1.30 \\
\hline 9. & I clear about my role in this organization. & 2.93 & 1.24 \\
\hline 10. & $\begin{array}{l}\text { I always create new innovations to ease my } \\
\text { work. }\end{array}$ & 2.75 & 1.27 \\
\hline 11. & $\begin{array}{l}\text { I have no problem sharing development costs } \\
\text { with my organization. }\end{array}$ & 2.83 & 1.31 \\
\hline 12. & $\begin{array}{l}\text { I have no idea of my comparative worth } \\
\text { within the labour market. }\end{array}$ & 3.17 & 1.27 \\
\hline 13. & I do commit with my organization. & 3.12 & 1.20 \\
\hline 14. & $\begin{array}{l}\text { I would recommend my organization to } \\
\text { others as a good place to work. }\end{array}$ & 2.74 & 1.30 \\
\hline 15. & $\begin{array}{l}\text { I do receive regular feedback from my } \\
\text { manager and organization. }\end{array}$ & 3.49 & 1.11 \\
\hline 16. & I do identify with my job at personal level. & 3.69 & 1.09 \\
\hline
\end{tabular}

The Table IV presented partial findings from the survey concerning the respondents' for the mean and standard deviation for organization support in the insurance company. 
Table IV summarized the sources of organizational support and their mean scores. Findings showed that respondents are particularly satisfied with their managing organizational change is the process of planning and implementing change in organizations in such a way as to minimize worker resistance and cost to the organization (4.22 mean, SD 0.86).

Today, for an organization to be successful and achieve the company's objectives, it is important that workers are satisfied with their work, because work occupies an important place in the lives of many people. The condition may affect not only their physical but also their social, psychological and spiritual well [11]. The success of any organization is dependent on how it attracts recruit, motivate and retain the workforce. Every organization should adopt an effective strategy in improving the quality work life for every individual. Every individual has different needs which can enhance their capacity to help the organization in achieving its vision and mission.

Table $\mathrm{V}$ summarized the findings that showed the respondents were particularly satisfied with the quality work life. Most of the workers indicated moderate satisfaction towards health care benefits, working environment, flexible work hours, relationship with co-workers and superiors as well as opportunity to work independently (Mean 3.68, S.D 1.226). Those relatively high scores came from respondents who are satisfied with their job and feel comfortable with facilities provide in the organization (3.54 mean, SD = 1.089).

TABLE V: MEANS AND STANDARD DEVIATIONS FOR QUALITY FOR WORK

\begin{tabular}{|c|c|c|c|}
\hline \multicolumn{4}{|c|}{ LIFE } \\
\hline No & Items & Mean & S.D. \\
\hline 1. & $\begin{array}{l}\text { I have enough freedom of decision } \\
\text { making in my job. }\end{array}$ & 3.68 & 1.226 \\
\hline 2. & $\begin{array}{l}\text { I feel well informed about what I going on } \\
\text { in organization. }\end{array}$ & 3.12 & 1.279 \\
\hline 3. & $\begin{array}{l}\text { I feel motivated to do my best for my } \\
\text { organization. }\end{array}$ & 3.27 & 1.234 \\
\hline 4. & $\begin{array}{l}\text { I feel comfortable with facilities provide } \\
\text { in my organization. }\end{array}$ & 3.54 & 1.089 \\
\hline 5. & I have authority and responsibility. & 2.06 & 1.085 \\
\hline 6. & I receive enough opportunities to perform. & 2.88 & 1.364 \\
\hline 7. & $\begin{array}{l}\text { I consult my higher authorities regarding } \\
\text { my job. }\end{array}$ & 1.97 & 1.635 \\
\hline 8. & I am satisfied with my productivity. & 3.37 & 1.027 \\
\hline 9. & I believe I will be working here & 3.10 & 1.293 \\
\hline 10. & $\begin{array}{l}\text { I am committed to doing my part at } \\
\text { improving the working relationship in the } \\
\text { organization. }\end{array}$ & 2.57 & 1.309 \\
\hline 11. & $\begin{array}{l}\text { I find good job retaining potential } \\
\text { company }\end{array}$ & 3.55 & 1.280 \\
\hline 12. & $\begin{array}{l}\text { My job requires that I keep learning new } \\
\text { things. }\end{array}$ & 2.97 & 1.419 \\
\hline 13. & My job requires that I work very fast. & 3.37 & 1.329 \\
\hline 14. & My job lets me use my past experience. & 3.09 & 1.379 \\
\hline 15 . & $\begin{array}{l}\text { My job makes me feel quite exhausted end } \\
\text { of a day. }\end{array}$ & 2.79 & 1.423 \\
\hline 16. & My thoughts go around in useless circles. & 2.96 & 1.253 \\
\hline
\end{tabular}

Overall findings show the characteristic of the respondents are particularly satisfied with organizational support and their quality of work life. As an insurance industry that emerged from recession in the era of the 2020, it is important for every insurance company to establish a senior management team to communicate effectively about business goals, policies and vision of the organization. Working relationship within the organization is as important as the combination from various areas of expertise.

\section{CONCLUSION}

To achieve the quality of work life, regular effort are required by the organizations which offer the employees more opportunities for their job effectiveness and collaboration on the overall effectiveness. Therefore, every organization with optional and influential effectiveness must looking for the ways to cause the workers to reach a degree of ability, apply their own ability and intelligence which can be accomplished through appropriate of quality work life. Quality work life movement represents a sort of organization culture or management approach which employees feel ownership, autonomy, responsibility and self- steam. Apparently the job satisfaction relies on the organizational support along the workers tenure of employment. Therefore, this study concerning quality of work life and organizational support can assist the insurance industry to design strategies and policies attractive and beneficial to satisfy employees and retain their best talent in the industry. The results of this survey intended to assist decision makers or management in insurance industry to review or to consider the supports provided to the workers. Perhaps, this study could be extended to cover broader aspects of job satisfaction, talented and quality of work life among workforce across industries.

\section{REFERENCES}

[1] J. M. George and G. R. Jones, Understanding and Managing Organizational Behavior, Addison-Wesley, Reading, MA, 1996.

[2] V. Gilgeous, Operations and the Management of Change, London: Pitman Publishing, 1997.

[3] J. L. Glassand and A. Finley, "Coverage and Effectiveness of family-responsive workplace policies," Human Resource Management Review, vol. 12, pp. 313-337, 2002.

[4] R. J. Riggle, D. R. Edmondson, and J. D. Hansen, “A meta-analysis of the relationship between perceived organizational support and OB outcomes: 20 years of research," Journal of Business Research, vol. 62, pp. 1027-1030, 2009.

[5] R. Eisenberger, R. Huntington, S. Hutchison, and D. Sowa, "Perceived organizational support," Journal of Applied Psychology, vol. 71, pp. 500-507, 1986.

[6] L. Rhoades and R. Eisenberger, "Perceived organizational support: A review of the literature," Journal of Applied Psychology, vol. 87, pp 698-714, 2002.

[7] E. H. Roger, Keeping Good People: Strategies for Solving the Dilemma of the Decade, McGraw-Hill, 1991.

[8] L. Firth, D. J. Mellor, K. A. Moore, and C. Loquet, "How can managers reduce worker intention to quit?" Journal of Managerial Psychology, vol. 19 , no. 2 , pp. 170-187, 2004.

[9] S. P. Robin, Organizational Behaviour: Concepts, Controversies and Applications, Englewood Cliff, NJ: Prentice-Hall, 1989.

[10] M. Mahathir. (2008). The Way Forward. Prime Minister's Office. [Online]. Available: http://www.pmo.gov.my

[11] The Star Online. (2012). Malaysian Not Happy at Works. [Online] Available: http://www.carreryou.com.my

[12] R. J. Straw and C. C. Heckscher, "Quality work life: New working relationships in the communication industry," Labor Studies Journal, vol. 9, pp. 261-274, 1984.

[13] D. K. Sharma, R. K. Sharma, and D. Ghosh, “A spatial decision support system for land management," International Journal of Computers and Applications, vol. 28, no. 1, pp. 50-58, 2006.

[14] M. Rose, "Disparate measures in the workplace: Quantifying overall job satisfaction," presented at the 2001 BHPS Research Conference, Colchester, United Kingdom.

[15] The Star Online. (2012). Why Job Hoppers-Hope. [Online]. Available: http://ecentral.my 
[16] R. Mcadam and A. Galloway, "Enterprise resource planning and organizational innovation: A management perspective," Industrial Management and Data Systems, vo1. 105, no. 3, pp. 280-290, 2005.

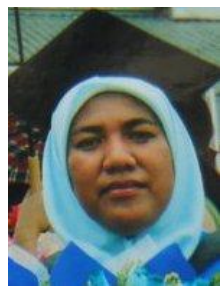

R. Rozaini started her career as a senior executive in one of the insurance company in Malaysia. She attained her first degree in public management in 2005 and master in human resources management 2008 from University Utara Malaysia, Malaysia. Currently pursuing her Ph.D. at Universiti Sains Islam Malaysia (USIM). In the past 16 years she has gained vast knowledge and experiences in insurance industry. She has taught of insurance courses for tertiary institutions in Malaysia. Her research supervisions have been in the areas of insurance in Malaysia. In 2013 she has published a case in "Integrated Muamalat Case Study" published by the penerbit USIM. She is actively involves in research papers in international refereed journals and conferences.

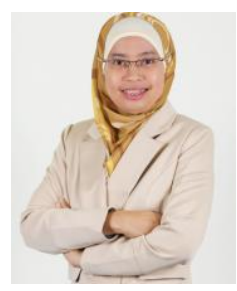

A. W. Norailis is a senior lecturer in the Faculty of Economics and Muamalat, Universiti Sains Islam Malaysia (USIM). She is a member of Malaysian muamalat association (MMA) and the Malaysian consumer and family economics association (MACFEA). She attained her first degree in industria economics in 2000 and master in science (productivity and quality enhancement) in the following year from Universiti Kebangsaan Malaysia.
In the middle of 2009, she had been awarded Ph.D. from the University of Stirling, Scotland. She joined SME corporation Malaysia (SME Corp) for three months in 2012 through USIM academic staff attachment program to gain industrial experiences and strengthen the networking with practitioners in small and medium enterprises (SMEs). She has published cases on umrah management and organizational issues in "Integrated Muamalat Case Study" published by the penerbit USIM. Presently, she involves in research on benchmarking, supply chain and umrah management as well as in activities organized by Malaysia Productivity Corporation (MPC) and SME Corp.

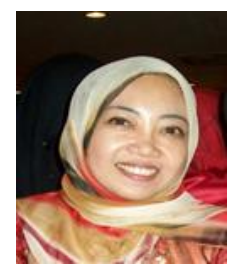

B. Aida is an industrial relation officer in the Ministry of Human Resources (MOHR), Malaysia. She has gained vast knowledge and experiences in employment matters as well as human resources issues during her twelve precious years serving in Labour Department, Putrajaya. At present, she works in National Wages Consultative Council, as secretariat formulating the national minimum wages for private sectors. She was formerly an advocate \& solicitor and a member of Malaysian Bar. She completed her first degree in LL.B (Hons) International Islamic University Malaysia in 1996. Completed her Master in Human Resources Management, Universiti Utara Malaysia in 2008, Currently pursuing her Ph.D. in Universiti Sains Islam Malaysia. 